\title{
STREETCARS AND REAL ESTATE RENTS WITH IMPLICATIONS FOR TRANSIT AND LAND USE PLANNING
}

4 Arthur C. Nelson, Corresponding Author

5 School of Landscape Architecture and Planning

6 University of Arizona

7 PO Box 210075

8 Tucson, AZ 85721

9 Corresponding Author Email: acnelson@email.arizona.edu

10 https://orcid.org/0000-0003-2578-3884

Robert Hibberd

13 School of Geography and Development

14 University of Arizona

151064 E Lowell St.

16 Tucson, AZ 85719

17 https://orcid.org/0000-0002-6606-6753

November 15, 2018

41 Keywords: Streetcar, real estate rent, streetcar planning, transit and land use planning,
42 transportation and land use planning, distance band, real estate value uplift

Keywords: Streetcar, real estate rent, streetcar planning, transit and land use
42 transportation and land use planning, distance band, real estate value uplift

Presentation at the $98^{\text {th }}$ Annual Meeting of the Transportation Research Board Washington, D.C.

January 13-16, 2019

Word Count: $\quad 5,900$ words

Tables and Figures: $6 \times 250=1,500$

Total Word Count: 7,400 total word equivalent

\section{ACKNOWLEDGEMENT}

This manuscript was prepared as part of the project sponsored by the National Institute of Transportation and Communities (Project Number 1103) with match provided by the City of Tucson, Regional Transportation Commission of Southern Nevada, Mid-America Regional Council, Wasatch Front Regional Council, Portland Metro and the University of Arizona. The authors also acknowledge CoStar for permission to use its data in the analysis reported in this article. 


\section{ABSTRACT}

44 Modern streetcars seemed to have emerged as the darling of America's downtown revival.

45 Planners however have little experience with market responses to modern streetcars to help guide

46 future efforts, or improve or expand current ones. This article is the first to report the association

47 between real estate rents and proximity to streetcar stations based on all streetcar systems

48 launched since 1990. It also uses multiple functional forms. The article shows that real estate

49 rents increase the closer office, retail and multifamily properties are to streetcar stations.

50 Analysis further tests outcomes using five functional forms: linear; semi-log; double-log;

51 quadratic; and fine-grained distance band (using one-eighth mile increments). It appears that the

52 distance band functional form specification may be more useful than others for transit and land

53 use planning purposes. Results suggest that streetcar planning and associated land use planning

54 should anticipate heightened demand for multifamily residential development near streetcar

55 stations perhaps displacing office development to about a half mile away. Retail activities may

56 benefit from additional level of competition for location near streetcar stations by both

57 residential and office development. Indeed, analysis finds that whereas multifamily residential

58 rent premiums with respect to streetcar station proximity extend a mile outward, office rent

59 premiums are lower closer to stations but rise rapidly about a half mile away, presumable

60 outbidding multifamily residential development. Retail activities take advantage of this

61 competition roughly to the area between the office and multifamily rent premium thresholds.

62 Implications for fixed guideway transit and land use planning practice are offered. 


\section{INTRODUCTION}

65 American streetcars flourished from the 1880s through the 1940s. To make way for automobiles,

66 they were mostly dismantled from the end of WWII to about 1960 [1]. What remained were

67 mostly heritage and tourist-dominated streetcars such as those seen in San Francisco,

68 Philadelphia and New Orleans. This began to change in the late 1990s through the rise of the so-

69 called modern streetcar. It has its genesis in Portland, Oregon, which started operations in 2001.

70 It is also the nation's most extensive streetcar network. Modern streetcars are no longer the

71 charming relic of a bygone era but have become key transportation mode choice options

72 especially in built up urban areas [2]. Since 2001, we count no fewer than 25 streetcar new

73 systems in operation, under construction, or planned as of this writing.

74 Portland's streetcar goals are similar to those of other systems built or being planned.

75 They include [3]:

Provide neighborhoods with convenient and attractive transportation alternatives.

Fit the scale and traffic patterns of existing neighborhoods.

Provide quality service to attract new transit ridership.

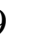

Reduce short inner-city auto trips, parking demand, traffic congestion and air pollution.

82 of whether and the extent to which modern streetcars influence the real estate market. Our

83 article helps close this gap.

84 In this article, we apply hedonic regression to estimate the association between streetcar

85 station proximity and office, retail and multifamily rents using several functional forms. We

86 apply our analysis to modern streetcar systems launched since the 1990s and operating in 
87 Atlanta, Charlotte, Cincinnati, Dallas, the District of Columbia (DC), Kansas City, Little Rock,

88 New Orleans, Portland, Salt Lake City, Seattle, Tacoma, Tampa, and Tucson. Our modeling

89 approach is generalizable to other systems.

90 This article begins with the research questions and proceeds to theory, research design,

91 general model, functional form, study area and specific model and data. This is followed by an

92 assessment of how the real estate market appears to capitalize proximity to streetcar stations in

93 the form of higher rents but that the nature of this rent uplift varies by functional form. We will

94 suggest that for transit and land use planning purposes, a fine-grained distance-band functional

95 form may be more informative than alternative ones.

96

97 RESEARCH QUESTIONS, THEORY, RESEARCH DESIGN, GENERAL MODEL,

FUNCTIONAL FORM, STUDY AREA, SPECIFIC MODEL and DATA

99 Research Questions

100 Our research questions are simply:

101

102 Is there an association between commercial real estate rent (per square foot) and

103 proximity to streetcar stops holding other factors constant?

104

105 Does the nature of association vary by functional form?

106

107 
The questions are guided by theory. Conventional urban location theory developed by

110 Alonso [4], Muth [5] and Mills [6] (also known as AMM) shows that in a monocentric city,

111 where all jobs are in the central business district (CBD), the cost of transportation increases as

112 distance increases from the CBD at a declining rate, as a function of increasing land area of the

113 commuting shed. Transportation costs thus affect land value so that the "bid rent" curve for land

114 also declines as distance increases. Where transportation costs are lowest, in the CBD, land

115 prices are highest. To afford higher land prices ("rent") in the CBD, more economic exchange is

116 needed, resulting in higher development intensities among office, retail, and high-value

117 multifamily housing land uses among others. Economic activities that cannot compete for CBD

118 locations are pushed outward to locations where they can outbid other land uses, a process called

119 urban land use invasion and succession [7].

120 In relaxing the strict monocentric city model, one can imagine the same principles at

121 work only at smaller scales that are distributed across a metropolitan area [8]. For instance, in

122 focusing transportation activity at nodes, rail transit stations can become small version of CBDs.

123 Economic activities will bid up land prices close to rail transit stations; lower value activity

124 moves away from transitions to location there they can outbid competing land uses. Numerous

125 studies show negative bid rent gradients with respect to distance from rail transit stations

126 suggesting these local level outcomes [9]. 


\section{Research Design}

The theory can be evaluated through static, cross-section quasi-experimental research

131 design. That is, using one period of time, one can test for the effect of streetcar station proximity

132 on real estate rents across an area, such as a metropolitan area, and across multiple metropolitan

133 areas with streetcar systems. Though analysis is not causative, associations can be used as

134 guidance for transit and land use planning purposes nonetheless.

\section{General Model}

Using these theoretical and research design foundations as a guide, we develop the

138 following general model to test the theory. It is adapted from Nelson [10]:

141 where:

$142 \mathbf{R}$ is the asking rent per square foot for property $i$;

$143 \mathbf{S}$ is the set of structural attributes of property $i$ including its architecture, mass, height, age and 144 effective age, interior amenities, flow efficiencies and so forth;

145 SES is the set of socioeconomic characteristics of the vicinity of property $i$ such as population 146 features, income, education;

$147 \mathbf{P}$ is a set of planning, zoning and other development restrictions applicable to property $i$;

$148 \mathrm{U}$ is a set of measures of urban form of the vicinity of property $i$ such as the nature of 149 surrounding land uses, terrain, physical amenities (such as parks), street characteristics 150 and related; 
$151 \mathbf{L}$ is a set of location attributes of property $i$ such as distance to downtown and other activity

152 centers, distance to nearest major highways including freeway/expressway ramps, and

153 distance to different public transit options; and

$154 \mathbf{M}$ is a set of metropolitan area controls. As metropolitan area conditions and markets vary between them, identifying the location of property $i$ within its respective market helps control for metropolitan-specific influences.

\section{$158 \quad$ Functional Form}

159 The choice of functional form and variable specification is important. Standard urban economic

160 theory posits that land value will decline with distance from the CBD or other high activity

161 nodes. Linear, semi-log, and double-log functional forms are the dominant forms reported in 162 literature [9].

163 The linear functional form assumes a straight line deduction in property value with 164 respect to distance away from a node, such as a transit station.

165 The semi-log functional form - where the dependent variable is logged - estimates the

166 percent change in value associated with a unit change in an independent variable. If the

167 dependent variable is price per square foot of real estate and the coefficient is -5.0 , the semi-log 168 interpretation is a $\$ 5.00$ per square foot value reduction for each mile away from the station.

169 The double-log functional form generates elasticities — continuously measured variables

170 on both sides of the equation are logged though categorical and binary variables are not. If the

171 station distance coefficient is -0.50 , the double-log estimates that a one percent increase in the

172 distance from a transit station will reduce value by 0.50 percent per square foot. 
174 arrange land uses to maximize economic benefits of transit stations. It may be that want to know

175 whether the market will respond favorably to land use and density allocations with respect to

176 distance from transit stations, and especially how far away. Lacking guidance from these

177 conventional functional forms, planners have settled on quarter-mile and half-mile planning

178 areas around stations, with very little empirical justification-more on this later.

179 A less used approach, the quadratic functional form, is specified such that the linear

180 distance term is squared and both included in analysis. It has the distinct advantage of

181 pinpointing the break point in the transit station distance curve.

182 In the context of rail transit, the concern is that rail stations themselves can be nuisances

183 such that real estate values and rents may be dampened very near them. As Nelson and

184 McClesky theorize [11], the market capitalizes both positive amenity effects of rail station

185 proximity as well as negative amenity effects, such as those associated with noise, such as

186 dispatching broadcasts at station platforms, and congestion, such as when vehicles use park and

187 ride lots during peak hours [12]. So long as positive amenity effects outweigh negative ones, the

188 bid rent gradient will be sloping downward and away from rail transit stations. In theory,

189 however, it is possible for negative amenity effects to outweigh positive ones. These interactions

190 are shown in Figure 1, described as follows:

191 The line $\mathrm{R}^{\mathrm{a}}$ shows the land rent (R) curve with full amenity ("a" for positive amenity)

192 value from a rail transit station, $\mathbf{u}_{0}$, outward to a point, $\mathbf{u}_{1}$, where the amenity effects of

193 rail transit proximity disappear, beyond which the overall market rent, unaffected by the

194 presence of the rail transit station, $\mathrm{R}^{\mathrm{m}}$ is revealed. 
Negative effects of rail transit stations are shown in line $\mathrm{R}^{\mathrm{n}}$ (" $\mathrm{n}$ " for negative amenity). As distance from the rail station increases, the negative amenity effects are reduced until they become zero at $\mathrm{u}^{1}$.

Positive and negative amenity effects interact in the market leading to overall positive or negative bid rent curves with respect to distance from rail transit stations to $\mathrm{u}_{1}$. Line $\mathrm{R}^{\mathrm{a}}+$ $\mathrm{R}^{\mathrm{n}}$ is revealed where overall positive amenity effects outweigh negative ones. Line $\mathrm{R}^{\mathrm{a}}+$

With a quadratic analytic approach, estimates of the revealed bid rent gradients with

208 respect to distance from rail transit stations may not detect the interaction between positive and 209 negative amenity effects. In our view, this requires a model wherein the distance effects of rail 210 transit stations are specified using the quadratic functional form. The first term, linear, reveals

211 the strongest of the two influences, positive or negative. In cases where value is affected

212 negatively by such sites as landfills, the linear term would be expected to have a negative

213 association with respect to landfill distance while the second term would be positive so that after

214 some distance, $\mathrm{u}_{1}$, the negative effect is offset [13]. In the case of rail transit stations, theory

215 suggests there would be an overall positive amenity effect with respect to station distance- the

216 first term - but it can be dampened by underlying negative amenities - the second term. 


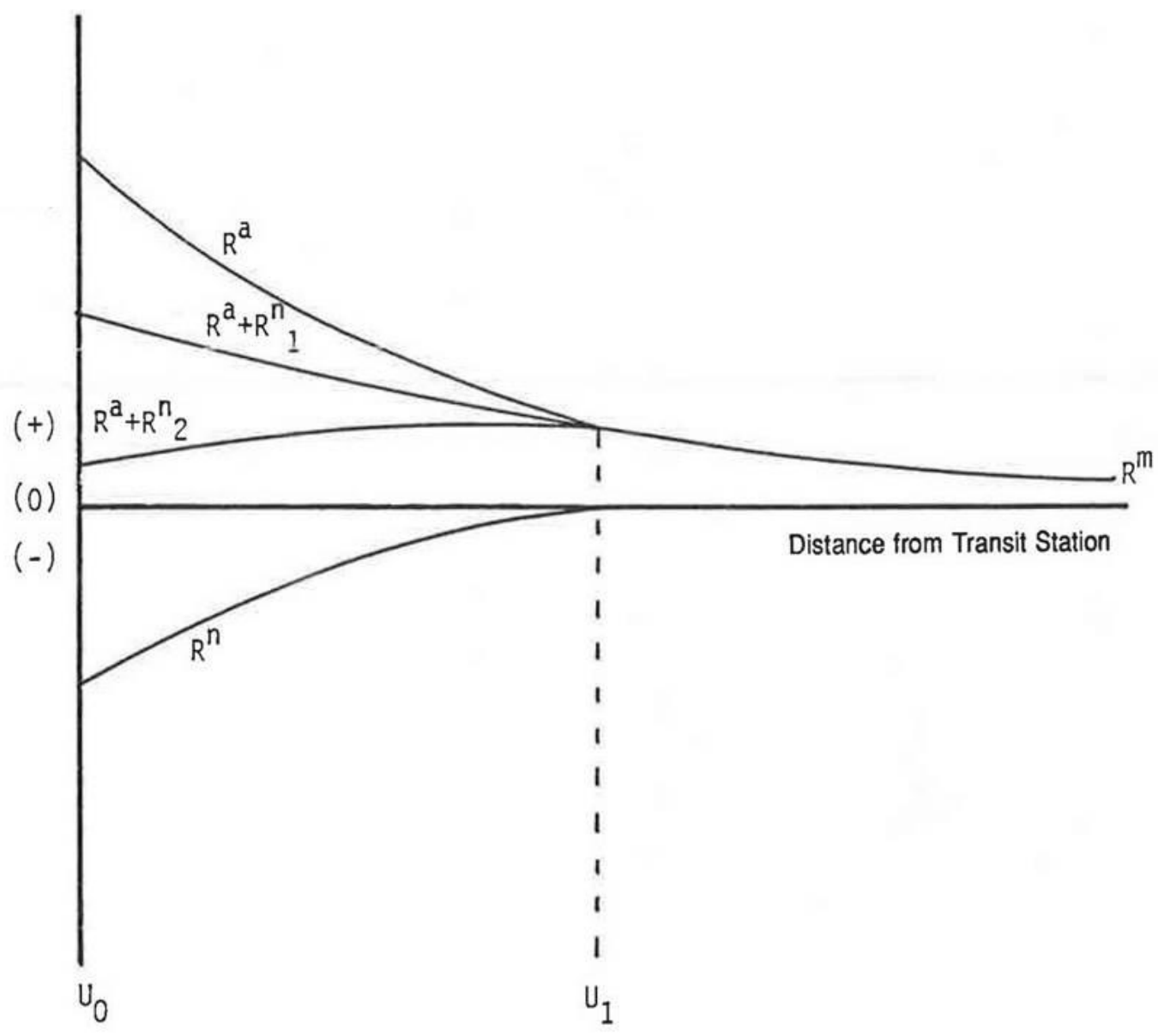

\section{Figure 1}

222 Positive Amenity $\left(\mathrm{R}^{\mathrm{a}}\right)$ and Negative Amenity $\left(\mathrm{R}^{\mathrm{n}}\right)$ influences of transition stations on proximate 223 property values and rents

224 Source: Nelson and McClesky [11].

225 
Mechanically, using a semi-log (log of the dependent variable) specification with the

227 quadratic distance form means, for instance, that if the station linear distance coefficient is -5.00

228 but the quadratic transformation coefficient is 10.00 , differentiating both terms results in -1.00 .

229 That is, the downward slope of the first term reaches minima at 1.00 mile then bends upward.

230 For planners, this suggests that the market responds to transit station proximity to one mile away.

231 Moreover, the equation can be mapped showing the decay in value with respect to distance. For

232 instance, using the quadratic transformation, Nelson et al. [14] estimated that 75 percent of the

233 office real estate rent lost with respect to distance from light rail stations occurred within 0.9

234 miles.

235 But quadratic functional forms may not be very useful either, especially if both signs are

236 in the same direction (increasing or decreasing value at a faster rate with respect to distance).

237 Even where signs are different, the smaller the second term relative to the first the flatter the

238 slope. For example, if the second term above is 1.00 , the minima is 10 miles which may not be

239 very useful to planners crafting plans around stations.

240 Distance bands offer a middle ground between knowing whether and the extent to which

241 real estate markets respond to transit stations usually within one quarter or one half mile [9]. But

242 that assumes all relevant interactions useful for planners to know occur only within those narrow

243 distance bands, and that those bands apply to all transit modes in all metropolitan areas.

244 Following Hibberd et al., [15] this article expands on and applies the distance band concept,

245 described in more detail below. 


\section{Study Area}

250 Given that literature has not reported rigorous research into the relationship between streetcars

251 and real estate values, or rent [10], we attempt to do so here. In particular, we apply the general

252 model with various functional forms to the 14 streetcar systems that started operations in the

253 United States since the 1990s. They include Atlanta, Charlotte, Cincinnati, Dallas, the District

254 of Columbia (DC), Kansas City, Little Rock, New Orleans, Portland, Salt Lake, Seattle, Tacoma,

255 Tampa, and Tucson. Where cities had existing heritage lines, such as New Orleans, we evaluate

256 only the newly constructed line. Our analysis is limited to the central counties within which these

257 streetcars operate — not all counties in their metropolitan areas. Specification details are reviewed

258 next.

\section{Specific Model and Data}

261 With two exceptions noted below, we operationalize the general model vectors and functional

262 forms here. Notably, we report the statistical association between rent per square foot for

263 office, retail and multifamily properties with respect to streetcar station proximity using linear,

264 semi-log, double log, quadratic and distance band functional forms, holding other factors

265 constant.

$266 \quad \mathbf{R}$ is the asking rent per square foot for property $i$ reported by CoStar during 2017. These

267 include all properties with space for rent from among office, retail, and multifamily real estate

268 projects. ${ }^{1}$ Analyses using linear and logged variations of the dependent variable are reported

269 below. The linear functional form estimates the dollar change in rent with respect to a one unit

${ }^{1}$ Normally, statistical analysis is applied to samples of a universe. In this case, the study includes the universe of all properties reported by CoStar. As CoStar data come from real estate brokerages participating in its network, the data exclude non-participating brokerages or entities and properties not for rent such as owner-occupied properties. 
270 change among individual independent variables such as median household income in the census

271 block group within which the subject property is located.

272 By logging the dependent variable, the semi-log model allows for coefficients to be

273 interpreted as the percent change in rent attributable to a one unit change in an independent

274 variable such as median household income.

275 By logging the dependent variable and continuously measured independent variables,

276 elasticities can be estimated show the percent change in rent associated with a one percentage

277 change in median household income.

278 S is the bundle of structure attributes for property $i$ reported by CoStar. This can include

279 occupancy characteristics noted below. For all properties, this includes:

280 Gross leasable area in building square feet with the expectation that there will be a

281 positive association between building area and rent because larger buildings presumably include

282 more amenities than smaller ones.

283 Effective year built which is the later of the year of construction or the year of renovation

284 as reported by CoStar with the expectation that newer buildings will command more rent than

285 older ones.

286 Vacancy rate with the expectation that the higher the vacant rate the lower the rent. This

287 may not always be the case however as high demand markets could result in high vacancy rates

288 as owners may wait for higher paying tenants. Accordingly, signs may not be predictable

289 especially considering that the study area is comprised of stable to rapidly growing central

290 counties.

$291 \quad$ For office properties structure attributes also include binary variables indicating whether

292 the building is considered Class A or Class B with the expectation that Class A rents will be 
293 higher than Class B which will be higher than Class C which is the referent building class. The

294 number of Floors is also included with the expectation that the taller the building the higher the 295 mean rent.

296 For retail, Floors are also included as a structure variable, as are the types of retail 297 structures including Power Center, Neighborhood Center, Community Center, Regional Mall, 298 Lifestyle Center and Outlet Mall all of which are expected to have a higher rent per square foot 299 than Strip Centers which are the referent.

$300 \quad$ For multifamily facilities, structure attributes include whether the buildings are classified 301 by CoStar as High Rise (15 or more floors), Mid Rise (four to 14 floors) or Garden Apartments

302 (one to three floors in a complex of four or more buildings) all of which are expected to 303 command higher rents per square foot than Low Rise structures (one to three floors in complex of 304 three or fewer buildings), the referent.

305 Multifamily also includes occupancy restrictions, notably Subsidized, Senior or Student 306 housing with Market Rate housing being the referent. The expectation is that relative to Market 307 Rate multifamily units, rents for Subsidized and Student housing will be lower but rents for 308 Senior housing will be higher.

309 The SES vector is comprised of two variables. The first is Median Household Income 310 from the five year sample of the 2016 American Community Survey (ACS) for the block group 311 within which a CoStar property is located, for which a positive association is expected with 312 respect to rent [16] The second is the Number of Households in the block group also from the 313 ACS where the expectation is the larger the number the higher the rent presumably because of 314 improved accessibility to workers [17]. 
The attributes for the $\mathbf{P}$ vector are missing because resources did not allow us to identify

317 planning and zoning conditions applied to the nearly 20,000 properties in our data base. We also

318 attempted to create a variable representing the $\mathbf{U}$ vector but were unsuccessful with calibration.

319 The attempt was patterned after Ewing and Hamidi's [18] entropy variable in which an index of

320 land use mix is calculated. Data were not available to do this at the block group level for the

321 study area. Adding these two vectors will be attempted in future research.

322 We divide the $\mathbf{L}$ vector into two location controls and the treatment, being streetcar

323 station proximity. The first location control is Distance from Downtown for which a negative

324 association is expected based on the AMM theory. Using Google Earth, we identified the central

325 most point of each downtown. The second location control is Distance from Freeway which is

326 defined as the nearest freeway or expressway ramp. Again, based on AMM, a negative

327 association is expected.

328 The treatment $\mathbf{L}$ variable is distance from the nearest streetcar station done in two ways.

329 The first is straight line distance of the subject property to the nearest streetcar station: Distance

330 from Streetcar. This is a continuously measured linear variable for the linear and semi-log

331 models, and its natural log for the double-log model. For the quadratic model, both the linear and

332 quadratic terms are used in the same question.

333 The other treatment variable is a series of distance band, DB defined as the location of

334 the subject property within one-eighth mile distance bands of the nearest streetcar stop to two

335 miles. The two mile distance was used to assure a maximum reasonable distance to estimate

336 distance band effects based on work by Nelson et al. [19] for Dallas office rental market light rail

337 transit effects (about 1.75 miles) and Petheram et al. [20] for the Salt Lake County multifamily

338 building light rail transit assessed value effects (about 1.25 miles). In the equations, for instance, 
DB $>0.125-<=0.250$ mile

342 means property $i$ is in the distance band that is greater than 0.125 miles but less than or equal to

3430.250 miles from the nearest street car transit station.

344 A measurement refinement that will be considered in future work is calculating the network 345 travel distance, rather than straight line.

346 The $\mathbf{M}$ vector is comprised of the individual central counties within which the streetcar

347 system of central cities operates. They include Atlanta, Charlotte, Cincinnati, Dallas, DC, Kansas

348 City, New Orleans, Portland, Salt Lake, Seattle, Tacoma, Tampa, and Tucson with the referent

349 being Little Rock.

$350 \quad$ Table 1 reports the mean statistics for all variables.

351 Our models include many times more data than used in most prior studies [9]. While we 352 have no a priori expectations of goodness of fit outcomes, literature suggests that ordinary least 353 squares hedonic (regression) analysis can explain between about one fifth to about three quarters 354 of the variation in the observed rent for the properties [9].

355 Nonetheless, we recognize that future work can benefit from further refinements. A

356 key refinement is to use network rather than Euclidian distance measures in future calibration of 357 distance bands. Though we believe the models are robust, spatial statistical methods will be 358 applied to future work to control for local dependence and the validity of model results.

359 We present results next followed by implications for transit and land use planning. 
362 Table 1

363 Variables Means

Variables

Dependent Variable

Rent per Square Foot, per year

Structure Controls

Gross Leasable Area, square feet

Effective Year Built

Vacancy Rate

Class A Office

Class B Office

Class $C$ (referent)

Floors

Power Center

Neighborhood Center

Community Center

Regional Mall

Lifestyle Center

Outlet Mall

Strip Center (referent)

High Rise

Mid Rise

Garden Apartments

Low Rise (referent)

Subsidized

Senior

Student

Market Rate (referent)

Demographic Controls

Median Household Income

Mean Block Group Households

Location Controls

Distance from Downtown, feet

Distance from Freeway, feet
Office Mean

$\$ 22.58$

83,582

1990

$28 \%$

$20 \%$

$54 \%$

$26 \%$

4.62

$2 \%$

$22 \%$

$7 \%$

$1 \%$

$1 \%$

$1 \%$

$66 \%$

$\$ 66,727$

782

43,394

7,531
Multifamily Mean

$\$ 17.16$

108,919

1977

$14 \%$

364 


\section{Streetcar Proximity}

Distance from Streetcar Stop, feet

35,756

$<=0.125$ mile

$>0.125-<=0.250$ mile

$>0.250-<=0.375$ mile

$>0.375-<=0.500$ mile

$>0.500-<=0.625$ mile

$>0.625-<=0.750$ mile

$>0.750-<=0.875$ mile

$>0.875-<=1.000$ mile

$>1.000-<=1.125$ mile

$>1.125-<=1.250$ mile

$>1.250-<=1.375$ mile

$>1.375-<=1.500$ mile

$>1.500-<=1.625$ mile

$>1.625-<=1.750$ mile

$>1.750-<=1.875$ mile

$<=2.000$ mile

$>2.000$ mile (referent)

Metropolitan Areas Controls

Atlanta

Charlotte

Cincinnati

Dallas

DC

Kansas City

New Orleans

Portland

Salt Lake

Seattle

Tacoma

Tampa

Tucson

Little Rock (referent)
$5 \%$

$4 \%$

$3 \%$

$2 \%$

$1 \%$

$1 \%$

$1 \%$

$1 \%$

$1 \%$

$1 \%$

$1 \%$

$1 \%$

$1 \%$

$1 \%$

$1 \%$

$1 \%$

$74 \%$

$11 \%$

$5 \%$

$8 \%$

$18 \%$

$9 \%$

$3 \%$

$1 \%$

$5 \%$

$7 \%$

$11 \%$

$4 \%$

$10 \%$

$7 \%$

$1 \%$
40,786

$3 \%$

$1 \%$

$1 \%$

$1 \%$

$1 \%$

$1 \%$

$1 \%$

$1 \%$

$1 \%$

$1 \%$

$1 \%$

$1 \%$

$1 \%$

$1 \%$

$1 \%$

$1 \%$

$82 \%$

$7 \%$

$4 \%$

$7 \%$

$19 \%$

$5 \%$

$4 \%$

$1 \%$

$3 \%$

$1 \%$

$11 \%$

$4 \%$

$9 \%$

$18 \%$

$7 \%$
11,427

$8 \%$

$5 \%$

$4 \%$

$4 \%$

$4 \%$

$5 \%$

$4 \%$

$3 \%$

$3 \%$

3\%

$3 \%$

$3 \%$

$3 \%$

$2 \%$

$3 \%$

$2 \%$

$41 \%$

$7 \%$

$5 \%$

$6 \%$

$14 \%$

$8 \%$

$4 \%$

$1 \%$

$11 \%$

$3 \%$

$22 \%$

$6 \%$

$5 \%$

$6 \%$

$2 \%$ 


\section{RESULTS AND DISCUSSION}

Tables 2, 3 and 4 report regression results for the five equations comprising the

372 functional forms used in this analysis, for office, retail and multifamily properties respectively.

373 Correlation matrices that are not reported for brevity do not reveal problematic collinearities

374 between them. Performance measures are reasonable. Notably, the coefficients of determination

$375\left(\mathrm{R}^{2}\right)$ are within expectations of prior literature [9]. Data for the $\mathbf{P}$ and $\mathbf{U}$ vectors, and perhaps

376 more refined property data may improve $\mathrm{R}^{2}$ but given the lack of collinearity especially among

377 the $\mathbf{L}$ and $\mathbf{P}$ variables, improvements will not change central tendencies.

378 Coefficients in bold are significant at the 0.05 or better level of the two-tailed t-test, since

379 directions of association are predicted. This excludes $\mathbf{M}$ vector controls for metropolitan areas

380 since there is no per se prediction of association; the only role of this vector is to control for

381 nuances of individual metropolitan areas relative to others. Also not highlighted are those DB

382 coefficients that are significant with or without the correct sign beyond the first insignificant DB.

383 This provides for a conservative estimate of the minimum distance from streetcar stations where

384 rent premiums dissipate.

385 For the most part, all control variables with significant coefficients have the correct signs 386 and reasonable magnitudes. Notably, Distance from Downtown variables in all models are all 387 significant and have the correct signs, confirming the AMM expectation for declining values 388 with respect to downtown distance. The Distance from Freeway variable is decidedly less robust, 389 however, as it is significant in only about half the equations though with the correct signs. In all 390 cases, however, the slopes are very flat suggesting rents change scant few pennies per mile away 391 from freeways. One reason may be the ubiquitous nature of freeway access across most 
metropolitan areas. We will not comment on the other control variables them for brevity,

393 preferring to highlight spatially related streetcar distance results and implications.

394 The linear and semi-log equations do not show insignificant associations between rent

395 and streetcar station distance in the office and retail models, though they are significant in the

396 multifamily model albeit with the incorrect sign in the linear model. The Distance from Streetcar

397 variable is significant with the correct sign in the office and retail double log models. In the

398 office mode, for instance, a one percent increase in the mean distance from a streetcar station is

399 associated with a one hundredth of one percent drop in mean rent per square foot—about 23

400 cents for every roughly 400 feet away which is not trivial. For retail it is higher at about 66 cents

401 per square foot for every 400 feet away. Not only is the double log coefficient for multifamily

402 insignificant, it is also very small, being about nine cents per square foot for about every 100 feet

403 away — which at 400 feet would be a reduction of about 36 cents per square foot.

404 Results for the quadratic equation are interesting for the retail and multifamily models.

405 Differentiating the linear and quadratic terms (and dividing by 5,280 feet in a mile), rents fall per

406 square foot to 7.45 miles for retail properties and 1.99 miles for multifamily. For office it would

407 be 4.29 miles if the linear term was significant though it had the correct sign.

408 In all four equations, the study areas are quite large (whole central counties) with mean

409 distances to downtown ranging around eight miles. Moreover, except for the multifamily cases,

41074 percent and 82 percent of the office and retail cases are beyond two miles from streetcar

411 stations. In effect, the statistical may understate market responsiveness close to stations because

412 the analysis is spread across large areas. One solution is to limit the analysis to just cases within

413 five miles, or two miles, or some other distance around streetcar stations. 
The distance band (DB) equations allow the relationship between rents and distance from

416 streetcar stations to be more accurately estimated, because each band is treated as its own

417 variable controlling for all others. Using this approach, we find significant associations between

418 rent and streetcar station distance up to 0.500 mile for office properties, 0.875 mile for retail

419 properties, and 1.000 mile for multifamily property.

420 For office properties, the DB rent coefficients are about the same to 0.375 mile-

421 suggesting a 5.5 percent to 7.0 percent rent premium within each band, but rising to about 10

422 percent and the $0.375-0.500 \mathrm{DB}$. In other words, in the first 0.375 mile, there is roughly a $\$ 1.50$

423 premium per square foot but in the last DB it rises to more than \$2.00. Distance band coefficients

424 are nearly all insignificant farther away. We speculate on the reason for this later.

425 For retail properties, there is roughly a 20 percent premium above the mean for being

426 within any of the DBs out to 0.875 mile, beyond which DB coefficients are all insignificant. The

427 rent premium is about $\$ 4.00$ per square foot. We speculate on why the retail rent premium with

428 respect to streetcar station distance is essentially constant to 0.875 mile but not beyond.

429 In contrast, coefficients for multifamily properties decline mostly steadily from the

430 innermost DB to 1.000 mile. Over these eight distance bands, mean rent premiums fall from

431 about $\$ 3.50$ to about 66 cents per square foot per year. Notably, multifamily rent premiums are

432 higher than those for office properties to about one 0.375 mile away where the office rent

433 premium with respect to streetcar station distance dominates. Though retail and multifamily rent

434 premiums are about the same to 0.375 mile, we suspect in areas close to streetcar stations that

435 retail activities may occupy the first level of a multilevel building where residential activities

436 occur on the upper levels. 
439 are illustrated in figure 2.

440 These insights are expanded in the last part of the article where we explore transit and 441 land use planning implications.

442

443

444

445

446

447

448

449

450 
Table 2

Office Rent Premiums with Respect to Streetcar Station Proximity by Functional Form

Variables
Constant
Structure Controls
Gross Leasable Area, Ln
Class A Office
Class B Office
Floors
Effective Year Built, Ln
Vacancy Rate, Ln
Demographic Controls
Median HH Income, Ln
Households, Ln
Location Controls
Distance from Downtown,
Distance from Freeway, Ln
Streetcar Proximity
Distance from Streetcar, Ln
Distance from Streetcar S
DB $<=0.125$ mile
DB $>0.125-<=0.250$ mile
DB $>0.250-<=0.375$ mile
DB $>0.375-<=0.500$ mile
DB $>0.500-<=0.625$ mile
DB $>0.625-<=0.750$ mile
DB $>0.750-<=0.875$ mile
DB $>0.875-<=1.000$ mile
DB $>1.000-<=1.125$ mile

\begin{tabular}{|c|c|c|c|c|}
\hline Linear & Semi-log & Double Log & Quadratic & Distance Band \\
\hline 5.326 & 2.315 & -1.388 & 2.331 & 2.338 \\
\hline$-2.070 \mathrm{E}-006$ & $-1.771 E-007$ & 0.291 & $-1.661 \mathrm{E}-007$ & $-1.531 \mathrm{E}-007$ \\
\hline 7.931 & 0.372 & 0.103 & 0.374 & 0.377 \\
\hline 1.699 & 0.126 & -0.003 & 0.129 & 0.129 \\
\hline 0.055 & 0.005 & 0.069 & 0.005 & 0.004 \\
\hline 0.005 & 0.000 & 0.425 & 0.000 & $0.000 \mathrm{E}+000$ \\
\hline-0.014 & -0.001 & -0.004 & -0.001 & -0.001 \\
\hline 3.610E-005 & 1.543E-006 & 0.106 & $1.558 \mathrm{E}-006$ & $1.581 \mathrm{E}-006$ \\
\hline 0.001 & 4.565E-005 & 0.023 & 4.257E-005 & 4.133E-005 \\
\hline$-6.856 \mathrm{E}-005$ & $-3.355 E-006$ & -0.035 & $-3.354 \mathrm{E}-006$ & $-2.059 \mathrm{E}-006$ \\
\hline 4.838E-006 & $9.346 \mathrm{E}-008$ & -0.008 & $4.530 \mathrm{E}-007$ & 4.777E-007 \\
\hline \multirow[t]{11}{*}{$9.638 \mathrm{E}-006$} & $9.365 \mathrm{E}-007$ & -0.010 & $-7.118 \mathrm{E}-007$ & \\
\hline & & & $1.570 \mathrm{E}-011$ & \\
\hline & & & & 0.057 \\
\hline & & & & 0.072 \\
\hline & & & & 0.056 \\
\hline & & & & 0.101 \\
\hline & & & & 0.033 \\
\hline & & & & 0.003 \\
\hline & & & & 0.057 \\
\hline & & & & 0.011 \\
\hline & & & & 0.061 \\
\hline
\end{tabular}


DB $>1.125-<=1.250$ mile

$\mathrm{DB}>1.250-<=1.375$ mile

$\mathrm{DB}>1.375-<=1.500$ mile

$\mathrm{DB}>1.500-<=1.625$ mile

$\mathrm{DB}>1.625-<=1.750$ mile

DB $>1.750-<=1.875$ mile

$<=2.000$ mile

\section{Metropolitan Areas Controls}

Atlanta

Charlotte

Cincinnati

Dallas

DC

Kansas City

New Orleans

Portland

Salt Lake

Seattle

Tacoma

Tampa

Tucson

\section{Model Performance}

Cases

Adjusted R2

Standard Error

F-ratio

$\begin{array}{rr}5.367 & 0.266 \\ -2.887 & -0.106 \\ 2.816 & 0.219 \\ 1.515 & 0.141 \\ 23.031 & 0.814 \\ -0.557 & 0.035 \\ -0.330 & 0.065 \\ 3.787 & 0.265 \\ 1.237 & 0.103 \\ 8.465 & 0.439 \\ 10.266 & 0.521 \\ 2.748 & 0.187 \\ 1.169 & 0.140 \\ & \\ 6.036 & 6036 \\ 0.410 & 0.521 \\ 3158026 & 0.3134173 \\ 175.943 & 274.285\end{array}$

0.072

$-0.063$

0.026

0.092

0.017

0.089

0.144

0.262

$-0.109$

0.218

0.136

0.810

0.026

0.046

0.246

0.100

0.433

0.373

0.188

0.130

0.130

6036

0.523

0.522

0.3130243

264.619

0.3127103 
Table 3

Retail Rent Premiums with Respect to Streetcar Station Proximity by Functional Form

\begin{tabular}{|c|c|c|c|c|c|}
\hline Variables & Linear & Semi-log & Double Log & Quadratic & Distance Band \\
\hline Constant & -3.903 & 1.512 & -0.467 & 1.540 & 1.403 \\
\hline \multicolumn{6}{|l|}{ Structure Controls } \\
\hline Gross Leasable Area, Ln & $-1.471 E-005$ & $-1.348 E-006$ & -0.075 & -1.347E-006 & $-1.364 \mathrm{E}-006$ \\
\hline Floors, Ln & 0.009 & 0.001 & 0.078 & 0.001 & 0.001 \\
\hline Effective Year Built, Ln & 0.010 & 0.001 & 0.183 & 0.001 & 0.001 \\
\hline Vacancy Rate, Ln & -0.010 & -0.001 & -0.005 & -0.001 & -0.001 \\
\hline \multicolumn{6}{|l|}{ Structure Type } \\
\hline Power Center & 4.809 & 0.268 & 0.364 & 0.298 & 0.281 \\
\hline Neighborhood Center & 0.142 & 0.021 & 0.105 & 0.038 & 0.030 \\
\hline Community Center & 2.282 & 0.113 & 0.183 & 0.132 & 0.129 \\
\hline Regional Mall & 12.261 & 0.475 & 0.477 & 0.512 & 0.476 \\
\hline Lifestyle Center & 4.279 & 0.273 & 0.332 & 0.280 & 0.262 \\
\hline Outlet Mall & 19.908 & 1.234 & 1.154 & 1.279 & 1.249 \\
\hline \multicolumn{6}{|l|}{ Demographic Controls } \\
\hline Median HH Income, Ln & 9.313E-005 & 4.047E-006 & 0.267 & 4.070E-006 & 4.070E-006 \\
\hline Households, Ln & 0.002 & $9.881 E-005$ & 0.088 & $9.738 \mathrm{E}-005$ & 8.732E-005 \\
\hline \multicolumn{6}{|l|}{ Location Controls } \\
\hline Distance from Downtown, Ln & -0.000 & -3.664E-006 & -0.046 & $-4.059 \mathrm{E}-006$ & $-2.025 \mathrm{E}-006$ \\
\hline Distance from Freeway, Ln & $-1.770 \mathrm{E}-006$ & 7.822E-007 & -0.014 & $1.754 \mathrm{E}-006$ & $9.365 \mathrm{E}-007$ \\
\hline \multicolumn{6}{|l|}{ Streetcar Proximity } \\
\hline Distance from Streetcar, Ln & 4.344E-005 & $9.843 \mathrm{E}-007$ & -0.033 & $-3.257 \mathrm{E}-006$ & \\
\hline Distance from Streetcar Squared & & & & 4.139E-011 & \\
\hline $\mathrm{DB}<=0.125$ mile & & & & & 0.195 \\
\hline DB $>0.125-<=0.250$ mile & & & & & 0.221 \\
\hline DB $>0.250-<=0.375$ mile & & & & & 0.155 \\
\hline DB $>0.375-<=0.500$ mile & & & & & 0.211 \\
\hline
\end{tabular}




$$
\begin{aligned}
& \mathrm{DB}>0.500-<=0.625 \text { mile } \\
& \mathrm{DB}>0.625-<=0.750 \text { mile } \\
& \mathrm{DB}>0.750-<=0.875 \text { mile } \\
& \mathrm{DB}>0.875-<=1.000 \text { mile } \\
& \mathrm{DB}>1.000-<=1.125 \text { mile } \\
& \mathrm{DB}>1.125-<=1.250 \text { mile } \\
& \mathrm{DB}>1.250-<=1.375 \text { mile } \\
& \mathrm{DB}>1.375-<=1.500 \text { mile } \\
& \mathrm{DB}>1.500-<=1.625 \text { mile } \\
& \mathrm{DB}>1.625-<=1.750 \text { mile } \\
& \mathrm{DB}>1.750-<=1.875 \text { mile } \\
& <=2.000 \text { mile }
\end{aligned}
$$

\section{Metropolitan Areas Controls}

Atlanta

Charlotte

Cincinnati

Dallas

DC

Kansas City

New Orleans

Portland

Salt Lake

Seattle

Tacoma

Tampa

Tucson

\section{Model Performance}

Cases

Adjusted R2

Standard Error

F-ratio
19.126

$-4.043$

1.478

$-0.169$

0.383

6.255

0.120

$-0.833$

$-2.916$

3002

0.344

10.4698837

57.272
0.077

$-0.172$

0.140

0.015

0.688

$-0.127$

0.198

0.149

0.107

0.368

0.490

0.059

$-0.074$

3002

0.350

0.4198923

58.53
0.141

0.129

0.222

$-0.076$

0.061

$-0.086$

$-0.048$

0.096

$-0.129$

$-0.042$

0.028

0.053

0.064

$-0.172$

0.136

0.004

0.707

$-0.128$

0.134

0.121

0.087

0.352

0.304

0.057

$-0.069$

3002

$\begin{array}{rrr}0.354 & 0.355 & 0.355 \\ 00266 & 0.4180765 & 0.417764\end{array}$
57.93 
Table 4

Multifamily Rent Premiums with Respect to Streetcar Station Proximity by Functional Form

Variables

Constant

\section{Structure Controls}

Gross Leasable Area, Ln

Average Unit Size, Ln

Effective Year Built, Ln

Vacancy Rate, Ln

High Rise

Mid Rise

Garden Apartments

Occupancy Controls

Subsidized

Senior

Student

Demographic Controls

Median HH Income, Ln

Households, Ln

\section{Location Controls}

Distance from Downtown, Ln

Distance from Freeway, Ln

\section{Streetcar Proximity}

Distance from Streetcar, Ln

Distance from Streetcar Squared

$\mathrm{DB}<=0.125$ mile

$\mathrm{DB}>0.125-<=0.250$ mile

$\mathrm{DB}>0.250-<=0.375$ mile

DB $>0.375-<=0.500$ mile

\begin{tabular}{|c|c|c|c|c|}
\hline Linear & Semi-log & Double Log & Quadratic & Distance Band \\
\hline-3.158 & $-2.236 E+000$ & -21.707 & $-2.311 E+000$ & -2.691 \\
\hline 1.037E-007 & $1.725 \mathrm{E}-007$ & 0.074 & $1.798 \mathrm{E}-007$ & 1.681E-007 \\
\hline$-1.925 \mathrm{E}-005$ & -3.316E-005 & -0.557 & $-3.288 \mathrm{E}-005$ & $-3.299 \mathrm{E}-005$ \\
\hline 0.002 & 0.001 & 3.045 & 0.001 & 0.001 \\
\hline 0.007 & 0.003 & 0.008 & 0.003 & 0.003 \\
\hline 0.570 & 0.344 & 0.205 & 0.328 & 0.294 \\
\hline 0.413 & 0.246 & 0.113 & 0.242 & 0.230 \\
\hline 0.040 & 0.021 & -0.037 & 0.028 & 0.034 \\
\hline-0.160 & -0.061 & -0.089 & -0.062 & -0.063 \\
\hline 0.193 & $6.800 \mathrm{E}-002$ & -0.046 & 7.300E-002 & 0.072 \\
\hline-0.117 & -0.231 & -0.183 & -0.238 & -0.252 \\
\hline 4.861E-006 & 3.031E-006 & 0.200 & 3.052E-006 & 3.003E-006 \\
\hline 9.922E-005 & $5.108 \mathrm{E}-005$ & 0.024 & 4.876E-005 & 4.122E-005 \\
\hline$-1.015 E-005$ & $-5.175 E-006$ & -0.098 & $-3.900 \mathrm{E}-006$ & $-1.717 \mathrm{E}-006$ \\
\hline$-7.612 E-006$ & -3.412E-006 & 0.007 & $-5.052 E-006$ & $-6.691 \mathrm{E}-007$ \\
\hline \multirow[t]{6}{*}{$1.486 \mathrm{E}-005$} & -6.166E-006 & -0.005 & $-3.857 \mathrm{E}-006$ & \\
\hline & & & $1.839 \mathrm{E}-010$ & \\
\hline & & & & 0.204 \\
\hline & & & & 0.161 \\
\hline & & & & 0.141 \\
\hline & & & & 0.138 \\
\hline
\end{tabular}




$$
\begin{aligned}
& \text { DB }>0.500-<=0.625 \text { mile } \\
& D B>0.625-<=0.750 \text { mile } \\
& D B>0.750-<=0.875 \text { mile } \\
& D B>0.875-<=1.000 \text { mile } \\
& D B>1.000-<=1.125 \text { mile } \\
& D B>1.125-<=1.250 \text { mile } \\
& D B>1.250-<=1.375 \text { mile } \\
& \text { DB }>1.375-<=1.500 \text { mile } \\
& D B>1.500-<=1.625 \text { mile } \\
& \text { DB }>1.625-<=1.750 \text { mile } \\
& \text { DB }>1.750-<=1.875 \text { mile } \\
& <=2.000 \text { mile }
\end{aligned}
$$

\section{Metropolitan Areas Controls}

Atlanta

Charlotte

Cincinnati

Dallas

DC

Kansas City

New Orleans

Portland

Salt Lake

Seattle

Tacoma

Tampa

Tucson

\section{Model Performance}

Cases

Adjusted R2

Standard Error

F-ratio
0.277

0.179

0.158

0.439

1.150

0.156

0.403

0.619

0.297

0.991

1.144

0.419

0.128

13,560

0.541

0.4991607

571.755

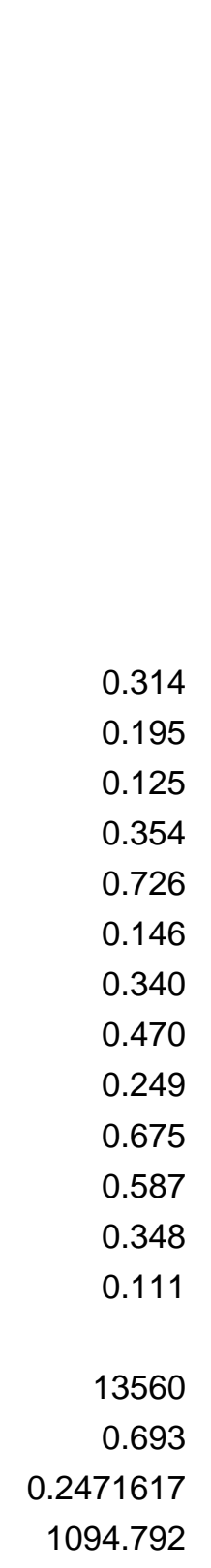

0.118

0.074

0.096

0.039

0.017

0.009

0.021

$-0.029$

0.008

0.001

$-0.034$

$-0.008$

0.257

0.186

0.117

0.359

0.750

0.113

0.286

0.472

0.264

0.695

0.648

0.349

0.175

0.189

13,560

13,560

0.601

0.2855292

699.193 


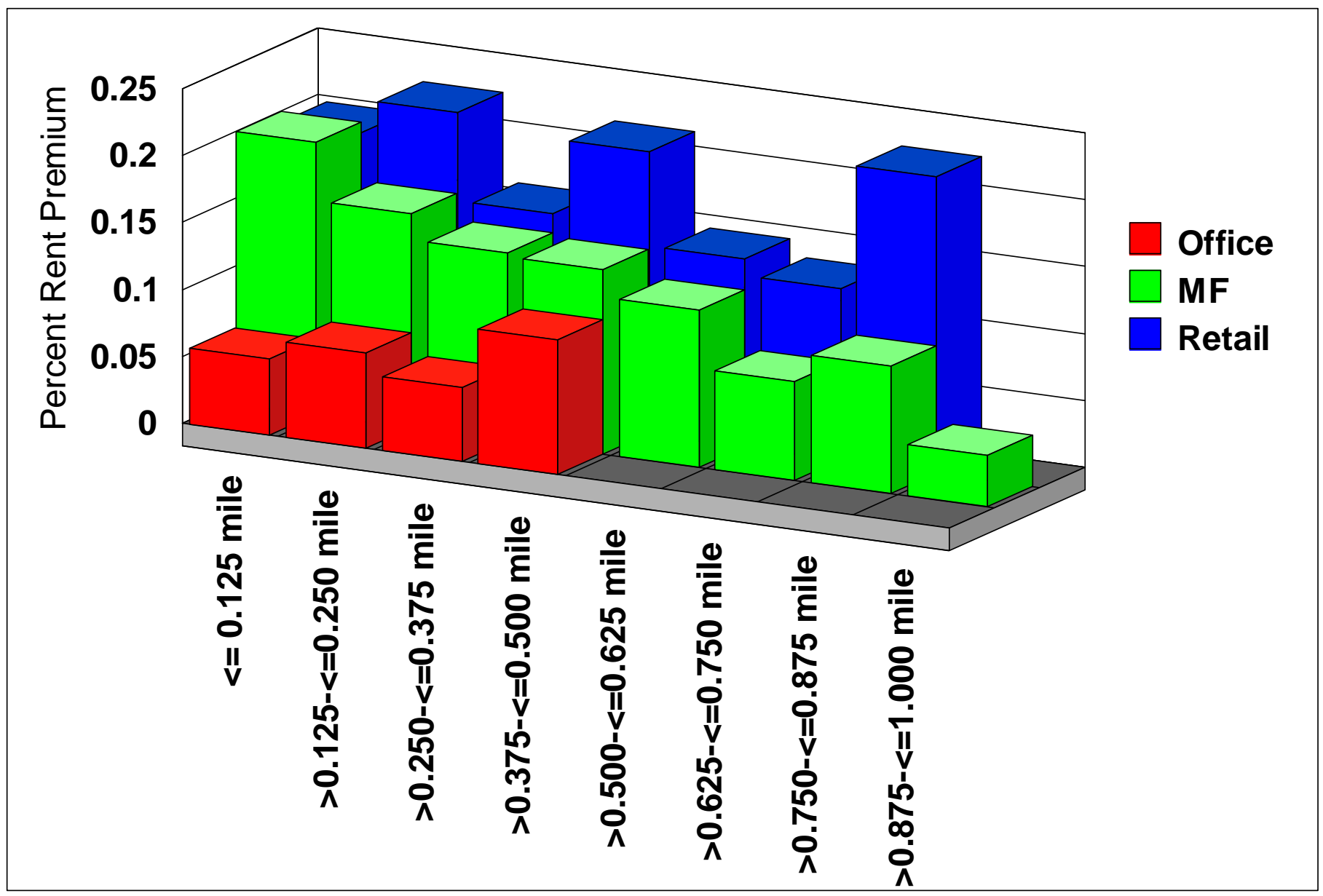

Figure 2

Percent rent change by distance band from streetcar stations. (MF means multifamily.) 


\section{IMPLICATIONS FOR TRANSIT AND LAND USE PLANNING}

This article may offer two main lessons for transit and land use planning. First of all, when evaluating transit systems for their effect on markets, the functional form of the model specification matters. Second, understanding how different land uses react in the market to different distances from transit stations also matters.

Though analysts tend to have their preferred analytic methodologies when they assess transit system impacts on jobs, housing, land uses, and real estate - many no doubt preferring the AMM semi-log or double log approaches — it may be that fine-grained distance band approaches are more informative for planning purposes. Unfortunately, distance band based studies in the past often used simple one-half mile [21] or one-half and one mile [10] buffers to assess differential effects of transit on development outcomes. In this study, one-eighth mile distance bands were used. This approach has the effect of creating unique, small area buffers around transit stations so that differences between small distances can be revealed. In contrast, analyses with large study areas may use functional forms that by design hide important, albeit subtle market effects that occur very close to stations with measurable effects up to a mile away [20]. Not that distance band based spatial analyses should be the only choice of functional forms but at least more effort should be made to apply this approach in future studies.

More practically are the implications of this study on streetcar planning, especially land use planning around streetcar stations. For one thing, we are not aware of any transit studies assessing differential real estate market effects with respect to small incremental distances from, stations. This would seem especially important in the case of streetcars because (a) those systems tend to serve more highly urbanized areas than other forms of fixed guideway transit systems and (b) there are simply no studies evaluating real estate market responsiveness to multiple land uses in the same area. 
A key insight from this study may that multifamily rental land uses appear to outbid office space near streetcar stations. Offices could be pushed away from streetcar stations but if they still need access to close-in locations where do they go? Because the multifamily rental premium declines rapidly as seen in Table 4 and illustrated in Figure 2, it may be that offices do not need to move very far: perhaps to about one half mile away. For its part, retail serves both residential and nonresidential needs so it benefits from the competition of both those land uses to roughly the area between where the office and multifamily rent premiums dissipate beyond significance. Certainly all three land use types can also occupy the same space in mixed use developments.

Modern streetcars in America are less than 20 years old and most are less than 10 years old. There is much to learn about how the market responds to them. Continually monitoring how streetcars add value to the real estate market, such as through rents, can help refine streetcar system and associated land use planning in the decades to come. Moreover, the lessons learned from this study may be applied to future analyses relating to how other types of transit modes influence the real estate market. 


\section{References}

1 Streetcars, A History https://www.american-rails.com/streetcars.html accessed July 30, 2018.

2 Hinners, Sarah J. and Michael A. Larice (2016). Assessing the Impacts of Streetcars on Economics, Equity, and Quality of Life. Salt Lake City, Utah: Metropolitan Research Center, University of Utah.

3 See www.portlandstreetcar.org.

4 Alonso W (1964). Location and Land Use: Toward a General Theory of Land Rent, Harvard University Press, Cambridge.

5 Muth RF (1969). Cities and Housing: The Spatial Pattern of Urban Residential Land Use, Third Series: Studies in Business and Society.

6 Mills ES (1967). An Aggregative Model of Resource Allocation in a Metropolitan Area, The American Economic Review, Papers and Proceedings, 57(2), pp 197-210. University of Chicago Press, Chicago.

7 Park, Robert Ezra, E. W. Burgess, Roderick Duncan McKenzie, and Louis Wirth. 1925. The city. Chicago, Ill: University of Chicago Press.

8 Amir H. Hajrasouliha \& Shima Hamidi (2017) The typology of the American metropolis: monocentricity, polycentricity, or generalized dispersion? Urban Geography 38:3, 420-444, DOI: $\underline{10.1080 / 02723638.2016 .1165386}$

9 Christopher D. Higgins \& Pavlos S. Kanaroglou (2016) Forty years of modelling rapid transit's land value uplift in North America: moving beyond the tip of the iceberg, Transport Reviews, 36:5, 610-634, DOI: 10.1080/01441647.2016.1174748

10 Arthur C. Nelson (2017). Transit and Real Estate Rents. Transportation Research Record: Journal of the Transportation Research Board. https://doi.org/10.3141/2651-03

11 Nelson, Arthur C. and Susan J. McClesky (1990). Elevated Rapid Rail Station Impacts on Single-Family House Values, Transportation Research Record, 1266: 173-180.

12 Nelson, Arthur C. (1992). Effects of Heavy-Rail Transit Stations on House Prices with Respect to Neighborhood Income, Transportation Research Record, 1359: 127-132.

13 Nelson, Arthur C. with John Genereux and Michelle Genereux (1992). Price Effects of Landfills on Vacant Residential Land Values. Journal of Urban Planning and Development 128137. 
14 Arthur C. Nelson (2017). Transit and Real Estate Rents. Transportation Research Record:

Journal of the Transportation Research Board. https://doi.org/10.3141/2651-03

15 Robert Hibberd et al. (2018). Functional Form in Hedonic Regression: Literature Review \& Test of Forms to Determine the End of Significance of Transit Proximity Effects on LVU. University of Arizona

16 Xiao, Yang (2016). Hedonic Housing Price Theory Review in Urban Morphology and Housing Market, pp. 11-40. New York: Springer.

17 Philip Stoker \& Reid Ewing (2014) Job-Worker Balance and Income Match in the United States, Housing Policy Debate, 24:2, 485-497, DOI: 10.1080/10511482.2013.852604

18 Reid Ewing and Shima Hamidi (2018). The Costs of Sprawl. London: Routledge.

19 Arthur C. Nelson, Dejan Eskic, Shima Hamidi, Susan J. Petheram, Jenny H. Liu, Reid Ewing. 2015. Office Rent Premiums with Respect to Distance from Light Rail Transit Stations in Dallas. Transportation Research Record DOI 10.3141/2500-13.

20 Petheram, Susan J., Arthur C. Nelson, Matt Miller and Reid Ewing (2013). Using the Real Estate Market to Establish Light Rail Station Catchment Areas: Case Study of Attached Residential Property Values in Salt Lake County with respect to Light Rail Station Distance. Transportation Research Record. 2357: 95-99. 